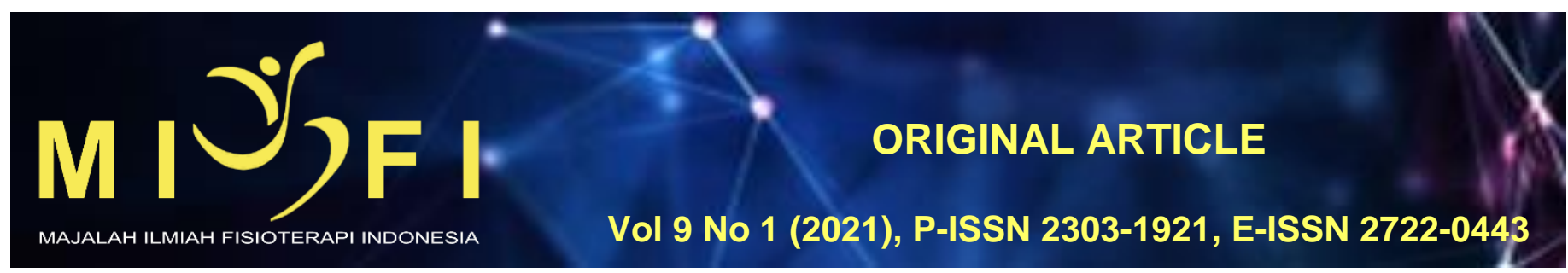

\title{
HUBUNGAN FLEKSIBILITAS OTOT HAMSTRING DENGAN KECEPATAN BERJALAN PADA LANJUT USIA DI DENPASAR
}

\section{Jeninha Ilandia Reis Henriques ${ }^{1}$, Made Hendra Satria Nugraha², Luh Made Indah Sri Handari Adiputra ${ }^{3}$, Indira Vidiari Juhanna ${ }^{4}$}

${ }^{1}$ Program Studi Sarjana Fisioterapi dan Profesi Fisioterapi, Fakultas Kedokteran,Universitas Udayana, Denpasar, Bali ${ }^{2}$ Departemen Fisioterapi, Fakultas Kedokteran, Universitas Udayana, Denpasar, Bali

${ }^{3,4}$ Departemen IImu Faal, Fakultas Kedokteran, Universitas Udayana, Denpasar, Bali Jenirehenriques@gmail.com

\begin{abstract}
ABSTRAK
Lanjut usia merupakan suatu kondisi dimana seseorang akan mengalami perubahan struktur dan fungsi dikarenakan usia yang sudah lanjut. Fleksibilitas adalah kemampuan sistem neuromuskular dan musculoskeletal dalam mengikuti suatu gerakan yang tepat dari sendi secara keseluruhan tanpa terjadi pengurangan serta lingkup gerak sendi yang bebas nyeri. Pada usia 60 tahun ke atas, lanjut usia mengalami perununan fungsi pada sistem muskuloskeletal yang menyebabkan penurunan fleksibilitas otot, sendi, fungsi kartilago, berkurangnya kepadatan tulang serta penurunan kekuatan otot terutama pada kekuatan otot bagian ekstremitas bawah dengan bertambahnya umur. Tujuan penelitian ini adalah untuk mengetahui hubugan fleksibilitas otot hamstring terhadap kecepatan berjalan lanjut usia di Denpasar. Penelitian ini merupakan penelitian analitik observasional dengan pengambilan data secara cross sectional. Peserta penelitian berjumlah sebanyak 62 orang. Fleksibilitas diukur dengan sit and reach test, sementara kecepatan berjalan diukur dengan 4 meters gait speed test. Analisis data yang digunakan adalah uji Sperman rho karena data tidak berdistribusi normal. Berdasarkan hasil penelitian didapatkan bahwa tidak terdapat hubungan antara fleksibilitas otot hamstring dengan kecepatan berjalan $(p=0,160)$ pada lanjut usia di Denpasar.
\end{abstract}

Kata kunci: fleksibilitas otot hamstring, kecepatan berjalan, lanjut usia

\section{THE RELATIONSHIP BETWEEN HAMSTRING FLEXIBILITY AND WALKING SPEED IN ELDERIY AT DENPASAR CITY}

\section{ABSTRACT}

Elderly is a condition where a person will experience structural and functional changes due to advancing age. Flexibility is the ability of the neuromuscular and musculoskeletal system to follow a precise motion of the joint as a whole without any reduction and pain-free range of motion. At the age of 60 years and over, the elderly experience a decrease in the musculoskeletal system which causes a decrease in muscle flexibility, joints, cartilage function, reduced bone density and decreased muscle strength, especially in the muscle strength of the lower extremities. The purpose of this study was to determine the relationship between hamstring muscle flexibility and walking speed of the elderly in Denpasar. This research is an observational analytic study with cross sectional data collection. The number of participants in the study was 62 people. Flexibility was measured by the sit and reach test, while walking speed was measured by the 4 meters gait speed test. The data analysis used was the Sperman rho test because the data were not normally distributed. Based on the results of the study, it was found that there was no relationship between hamstring muscle flexibility and walking speed $(p=0,160)$ in elderly people in Denpasar.

Keywords: elderly, hamstring muscle flexibility, walking speed

\section{PENDAHULUAN}

Lanjut usia merupakan individu yang telah mencapai usia 60 tahun ke atas. Menurut pandangan ahli tedapat 2 macam perbedaan lansia berdasarkan kategori umum, yaitu: umur kronologi dan umur biologi. Umur kronologi adalah umur yang dicapai seseorang dalam kehidupannya dihitung dengan kalender, sementara umur biologi yaitu usia yang sebenarnya. Indeks umur biologis biasanya diketahui dari pematangan jaringan. Hal inilah yang mendasari bahwa orang-orang dengan umur kronologis yang sama belum tentu memiliki penampilan fisik dan mental yang sama. ${ }^{(1)}$

Fleksibilitas yang menurun menyebabkan lansia mengalami kekakuan dan nyeri ketika melakukan suatu kegiatan dan aktivitas keseharian. Hal ini akan berdampak buruk jika tidak segera mendapatkan penanganan atau latihan fisik yang dapat menjaga fleksibilitas pada lansia. Latihan yang diberikan harus memperhatikan aspek kesehatan dan kemampuan lansia secara individual.(1)

Penurunan fungsi tubuh pada lansia akan mengakibakan permasalahan gangguan gerak dan fungsi lansia. Lansia mengalami perununan fungsi jalan, penurunan fungsi keseimbangan, penurunan kemampuan fungsional, serta penurunan kemandirian dalam aktivitas kehidupan sehari-hari. Penurunan tersebut pada umumnya mengarah pada kemunduran kesehatan fisik dan psikis yang pada akhirnya akan berpengaruh pada aktivitas hidup sehari-hari. Menurut WHO bahwa batasan-batasan umur pada lansia dari waktu ke waktu berbeda yaitu usia pertengahan antara usia 45- 
59 tahun, Iansia elderly antara usia 60-74 tahun, lansia old antara 75-90 tahun, dan usia lansia sangat tua diatas usia 90 tahun. (2)

Penurunan fleksibilitas tubuh dapat menyebabkan risiko jatuh pada lansia. Pada prinsipnya mencegah terjadinya resiko jatuh pada lansia sangat penting dan lebih utama daripada mengobati akibatnya. Untuk mencegah risiko jatuh dibutuhkan suatu latihan fisik yang dapat meningkatkan keseimbangan, fleksibiliras, serta dan kecepatan jalan. (2) Setiap individu memiliki fleksibilitas yang berbeda-beda. Fleksibilitas tergantung pada struktur sendi, otot yang melewati sendi, usia, jenis kelamin, suhu tubuh, tonus otot, kekuatan otot, kelelahan, dan emosi. Berjalan adalah bagian yang esensial dalam kehidupan sehari-hari. Setiap individu mempunyai cara berjalan yang unik yang kadangkala merupakan ciri khas dari individu yang bersangkutan. Pola jalan atau gait ialah cara seseorang berjalan yang dikarakteristikan oleh ritme, irama, langkah, jarak langkah, dan kecepatan. Kecepatan berjalan pada lansia berbeda dengan usia lainnya. Pada lansia terjadi penurunan kualitas musculoskeletal. Akibatnya keseimbangan, kekuatan, dan fleksibilitas untuk mempertahankan tes yang direkomendasikan untuk mengetahui tanda kemampuan fungsional dari lansia cenderung mengalami penurunan. Apabila kecepatan berjalan lansia kurang maka akan meningkatkan faktor risiko seperti kecacatan, ganguan kognitif, serta risiko jatuh. ${ }^{(3)}$

Menurut penelitian sebelumnya di Inggris tedapat 10.255 lansia di atas usia 75 tahun mengalami gangguan fisik seperti: gangguan sendi (55\%), keseimbangan (50\%), fungsi kognitif (45\%), penglihatan (35\%), pendengaran (35\%), kelainan jantung (20\%), sesak napas (20\%), serta gangguan miksi atau mengompol (10\%). Dari sekian banyak gangguan yang terjadi pada lansia dapat mengakibatkan menurunnya kualitas hidup serta usia harapan hidup. Permasalahan yang terjadi pada lansia adalah perubahan fungsional otot yaitu terjadi penurunan kekuatan otot dan fleksibilitas otot, penurunan fungsi propioseptif serta kecepatan, ganguan sistem vestibular, visual dan waktu reaksi. ${ }^{(4)}$

Dampak dari perununan fungsi pada lansia adalah peurunan massa otot atau atropi. Penurunan massa otot ini merupakan faktor penting yang mengakibakan penurunan kekuatan otot dan daya tahan otot. Sebanyak $90,9 \%$ lansia yang tinggal di panti atau rumah perawatan mengalami penurunan kekuatan otot. (5)(6)

Hingga saat ini belum banyak penelitian yang meneliti mengenai hubugan fleksibilitas otot hamstring dengan kecepatan berjalan lajnut usia di Denpasar. Berdasarkan latar belakang diatas, maka peneliti tertarik untuk melakukan penelitian dengan judul Hubungan Fleksibilitas Otot Hamstring dengan Kecepatan Berjalan Lanjut Usia di Denpasar.

\section{METODE}

Penelitian ini telah lulus kelaikan etik dengan No. 2410/UN/14.2.2.VII.14/IP/2019 dari Komisi Etik Penelitian (KEP) Fakultas Kedokteran Universitas Udayana/ Rumah Sakit Umum Pusat Sanglah Denpasar. Peneltian ini merupakan penelitian observasional analitik dengan pengambilan data secara cross sectional. Penelitian dilaksanakan pada bulan September 2019 di Banjar Gaduh dan Banjar Tengah Sesetan Denpasar. Sampel penelitian yaitu lanjut usia yang sesuai dengan kriteria inklusi dan eksklusi dengan menggunakan purposive sampling. Adapun kriteria inklusi meliputi: (1) Sukarela bersedia untuk menjadi peserta penelitian dari awal sampai akhir penelitian, (2) lansia berjenis kelamin wanita dan berumur 60 sampai 64 tahun, dan (3) dapat mengikuti instruksi. Sementara, kriteria eksklusi meliputi: lansia yang menderita sakit berat yang membutuhkan perawatan intensif di rumah sakit. Peserta penelitian berjumlah 62 orang.

Variabel dependen dalam penelitian ini yaitu kecepatan berjalan, variabel independennya adalah fleksibilitas otot hamstring. Fleksibilitas diukur dengan sit and reach test, sementara kecepatan berjalan diukur dengan 4 meters gait speed test. Analisis data pada penelitian ini menggunakan SPSS dengan melakukan analisis univariat untuk mengetahui kecepatan berjalan dan fleksibilitas otot hamstring dan analisis bivariat untuk mengetahui hubugan 2 variabel dengan menggunakan Uji Spearman Rho Test dengan tingkat signifikansi yang digunakan yaitu $(p<0,05)$.

\section{HASIL}

Dibawah ini merupakan karakteristlk peserta penelitian berdasarkan usia sebagai berikut:

Tabel 1. Distribusi Berdasarkan Usia

\begin{tabular}{ccc}
\hline Kelompuk Usia (tahun) & Frekuensi (f) & Presentase (\%) \\
\hline 60 tahun & 7 & 11,3 \\
61 tahun & 14 & 22,6 \\
62 tahun & 8 & 12,9 \\
63 tahun & 7 & 11,3 \\
64 tahun & 26 & 41,9 \\
Jumlah & 62 & 100,0
\end{tabular}

Berdasarkan Tabel 1 diketahui responden terbanyak ialah pada usia 64 tahun yaitu sejumlah 26 orang (41,9\%), pada usia 61 tahun sejumlah 14 orang $(22,6 \%)$, pada usia 62 tahun sejumlah 8 orang $(12,9)$ serta pada usia 60 dan 63 tahun sejumlah 7 orang $(11,3 \%)$.

Tabel 2. Distribusi Berdasarkan Kecepatan Berjalan dan Fleksibilitas Otot Hamstring

\begin{tabular}{cc}
\hline Variable & Mean \pm Standar Deviation \\
\hline Kecepatan berjalan & $0,88 \pm 0,25$ \\
Fleksibilitas otot hamstring & $11,13 \pm 1,06$ \\
\hline Total & 62
\end{tabular}

Berdasarkan Tabel 2 diketahui bahwa rata-rata kecepatan berjalan lansia yaitu $0,88 \mathrm{~m} / \mathrm{s}$ dimana masuk ke dalam kategori di bawah rata-rata usia 60-64 tahun yang semestinya dapat ditempuh dengan kecepatan 1,24 m/s. Ratarata fleksibilitas otot hamstring pada lansia yaitu $11,13 \mathrm{~cm}$ yang masuk ke dalam kategori sangat kurang. 
Tabel 3. Uji Normalitas Fleksibilitas Otot Hamstring dan Kecepatan Berjalan lansia

\begin{tabular}{cc}
\hline Variable & $\mathrm{P}$ \\
\hline Kecepatan berjalan & 0,000 \\
Fleksibilitas otot hamstring & 0,000 \\
\hline
\end{tabular}

Berdasarkan tabel 3 diatas dikarenakan semua data tidak berdistribusi normal $(p<0,05)$, maka digunakan uji spearman rho untuk mengetahui hubungan fleksibilitas otot hamstring dan kecepatan berjalan lanjut usia.

Tabel 4. Hubungan Fleksibilitas Otot Hamstring dan Kecepatan Berjalan Lanjut Usia

\begin{tabular}{cc}
\hline Korelasi Variabel & $\mathrm{P}$ \\
\hline Fleksibilitas otot hamstring dan kecepatan berjalan & 0,160 \\
\hline
\end{tabular}

Untuk mengetahui hubungan antara variabel dependen dan independen, maka dilakukan uji spearman rho. Berdasarkan tabel 4 pada hasil penelitian menunjukkan bahwa tidak terdapat hubungan antara fleksibilitas otot hamstring terhadap kecepatan berjalan pada lansia $(p=0,160)$ di Banjar Gaduh dan Banjar Tengah, Sesetan, Denpasar.

\section{DISKUSI \\ Karakteristik Peserta Penelitian}

Penelitian ini dilakukan pada bulan September 2019 di Banjar Tengah dan Banjar Gaduh Sesetan, Denpasar. Pada penelitian ini karakteristik responden berdasarkan usia diambil dengan kriteria inklusi lansia yang berusia 60-64 tahun, sehingga persebaran umur yang didapatkan pada penelitian ini adalah rentang usia 60-64 tahun yang didapat dari data lansia melalui assessment fisioterapi. Dari total lansia yang didapatkan 62 orang yang termasuk dalam kriteria inklusi, untuk kriteria eksklusi tidak ada. Sesuai dengan besar sampel yang telah ditentukan maka didapatkan total sampel sebanyak 62 lansia yang dilakukan dengan teknik purpose sampling. Karakteristik lainnya yang dikaji adalah fleksibilitas hamstring dan kecepatan berjalan lansia. Rata-rata fleksibilitas otot hamstring pada lansia yaitu $11,13 \mathrm{~cm}$ yang masuk ke dalam kategori sangat kurang. Rata-rata kecepatan berjalan lansia yang didapatkan yaitu $0,88 \mathrm{~m} / \mathrm{s}$ dimana masuk ke dalam kategori di bawah rata-rata usia 60-64 tahun yang semestinya dapat ditempuh dengan kecepatan $1,24 \mathrm{~m} / \mathrm{s}$.

Fleksibilitas sangat erat kaitannya dengan lingkup gerak sendi karena semakin rendah tingkat fleksibilitas seseorang maka akan rendah juga lingkup gerak sendi yang dimiliki seseorang. Turunnya kemampuan lingkup gerak sendi memberikan efek langsung terhadap kegiatan seseorang. Terbatasnya ruang gerak sendi yang membuat seseorang menjadi tidak fleksibel akan menjadikan seseorang rentan terhadap cedera, baik itu cedera otot maupun tulang. Perempuan memiliki lebih banyak akumulasi lemak daripada otot. Struktur lemak yang lebih lunak dibandingkan dengan otot akan menambah tingkat fleksibilitas perempuan. Ditambah dengan adanya hormon relaxin yang mempengaruhi pergerakan panggul dan besarnya pelvis pada perempuan juga menambah tingkat fleksibilitas. Hal tersebut menjelaskan data yang peneliti dapatkan pada penelitian ini, dimana seluruh lansia yang digunakan sebagai peserta penelitian berjenis kelamin perempuan.

\section{Hubungan antara Fleksibilitas Otot Hamstring terhadap Kecepatan Berjalan pada lansia}

Dalam posisi berdiri, respon motor efektor akan mempertahankan sikap dan keseimbangan gerakan yang dilakukan oleh suatu kelompok sendi dan otot dari kedua sisi tubuh. ${ }^{(7)}$ Penurunan fleksibilitas dapat mengakibakan penurunan keseimbangan. Jika keseimbangan lanjut usia tidak terkontrol akan meningkatkan risiko jatuh. ${ }^{(8)}$

Otot hamstring memiliki gerak fungsional dasar untuk knee flexion, sebagai muscle accessory untuk gerakan hip extension dan gerakan eksternal serta internal dari gerakan rotasi hip. Hamstring juga merupakan otot tonik, yang berfungsi sebagai otot stabilitator postural, dan memiliki serat serabut otot yang tebal yang memiliki kandungan myoglobin dan kapasitas oksidatif tinggi sehingga tahan terhadap kelelahan yang cukup tinggi. Perununan kemampuan muskuloskeletal dapat menurunkan aktivitas fisik dan latihan. Fleksibilitas otot hamstring yang memadai dibutuhkan untuk dapat melakukan aktivitas sehari-hari secara efisien. Jika otot mengalami pemendekan akan mempengaruhi keseimbangan kerja otot sehingga dapat memunculkan ganguan aktivitas. ${ }^{(9)}$

Fleksibilitas merupakan kemampuan otot untuk mengulur atau memanjang semaksimal mungkin sehingga tubuh dapat bergerak sesuai dengan lingkup gerak sendi yang maksimal dan disertai rasa nyaman. Fleksibilitas merupakan faktor penentu untuk memperoleh gerakan pada manusia.(10) Salah satu otot yang memegang peranan penting dalam aktivitas adalah otot hamstring. Fungsi otot hamstring sebagai efektor masuk kedalam fase terminal swing pada otot-otot sebelah anterior ankle tetap aktif untuk mempertahankan ankle dalam posisi netral selama subphase terminal swing. Tugas utama dari sistem efektor sendiri adalah mempertahankan pusat gravitasi tubuh ketika berjalan. ${ }^{(11)}$

Lanjut usia rentan mengalami banyak perubahan salah satunya fleksibilitas. Dengan bertambahnya usia terjadi perubahan kolagen dan elastin. Setelah kolagen mencapai puncak fungsi atau daya mekanik karena penuaan, daya elastis dan kekuatan otot kolagen akan menurun karena mengalami perubahan pada kolagen menyebabkan turunnya fleksibilitas pada lanjut usia dan berpengaruh terhadap penurunan kecepatan berjalan. ${ }^{(12)}$

Pada penelitian ini terlihat bahwa tidak tedapat hubungan antara fleksibilitas otot hamstring dan kecepatan berjalan $(p=0,160)$. Hal ini disebabkan karena terdapat beberapa kelemahan dalam penelitian ini yang dapat menjadi variabel perancu/cofounding variable, diantaranya: indeks massa tubuh yang tidak dikontrol serta kondisi psikologis seperti tingkat atensi/perhatian pada lansia yang berperan dalam mengatur kecepatan berjalan. 


\section{SIMPULAN}

Berdasarkan hasil penelitian yang telah dilakukan maka dapat disimpulkan bahwa tldak terdapat hubungan antara fleksibilitas otot hamstring dengan kecepatan berjalan lanjut usia di Denpasar. Penelitian selanjutnya diharapkan untuk dapat mengontrol variabel seperti indeks massa tubuh dan tingkat atensi lanjut usia yang berperan dalam mengatur kekuatan berjalan.

\section{DAFTAR PUSTAKA}

1. Alim A. Latihan Fleksibilitas dengan Metode PNF. Artik e-staff FIK UNY [Internet]. 2012;1-9. Available from: http://staffnew.uny.ac.id/upload/132319843/penelitian/LATIHAN+FLEKSIBILITAS+DENGAN+METODE+PNF.pdf

2. Nugraha MHS, Wahyuni N, Muliarta IM. Pelatihan 12 Balance Exercise Lebih Meningkatkan Keseimbangan Dinamis daripada Balance Strategy Exercise pada Lansia di Banjar Bumi Shanti, Desa Dauh Puri Kelod, Kecamatan Denpasar Barat. Majalah IImiah Fisioterapi Indonesia. 2016; 4(1)

3. Brach JS, VanSwearingen JM. Physical impairment and disability: Relationship to performance of activities of daily living in community-dwelling older men. Phys Ther. 2002;82(8):752-61.

4. Fatimah RN. Diabetes Mellitus Tipe 2. J Major. 2015;4(5):93-101.

5. Nitz JC, Choy NL. The efficacy of a specific balance-strategy training programme for preventing falls among older people: A pilot randomised controlled trial. Age Ageing. 2004;33(1):52-8.

6. Pujiastuti S, Utomo B. Fisioterapi pada Lansia. Jakarta: EGC; 2003.

7. Suhartono. Pengaruh Kelemahan Otot Anggota Gerak Bawah Terhadap Keseimangan Postural Pada Subjek Sehat. Universitas Diponegoro; 2005.

8. Stanley M, Gauntlett P. Buku Ajar Keperawatan Gerontik. Jakarta: EGC; 2007.

9. Yu B, Queen RM, Abbey AN, Liu Y, Moorman CT, Garrett WE. Hamstring muscle kinematics and activation during overground sprinting. J Biomech. 2008;41(15):3121-6.

10. Kisner C, Colby LA. Therapeutic Exercise Foundations and Techniques, Sixth Edition. 6th ed. Philadelphia: Davis Company; 2012.

11. Neumann D. Kinesiology of the Musculoskeletal System Foundations for Rehabilitation. United States: Mosby Elsevier;

12. Kang HG, Dingwell JB. Effects of walking speed, strength and range of motion on gait stability in healthy older adults. J Biomech. 2008;41(14):2899-905. 